\title{
A possible role of BDNF in prostate cancer detection
}

\author{
E. BRONZETTI ${ }^{1}$, M. ARTICO ${ }^{4}$, F. FORTE ${ }^{1,2}$, G. PAGLIARELLA ${ }^{3}$, \\ L.M. FELICI ${ }^{1}$, A. D'AMBROSIO ${ }^{1}$, G. VESPASIANI ${ }^{3}$ and B. BRONZETTI ${ }^{5}$ \\ ${ }^{1}$ Department of Cardiovascular, Respiratory Sciences and Morphology, University of Rome 'La Sapienza'; \\ ${ }^{2}$ Service of Urology, Israelitic Hospital, Rome; ${ }^{3}$ Chair of Urology, University of Rome 'Tor Vergata'; \\ ${ }^{4}$ Department of Human Physiology and Pharmacology 'V. Erspamer', University of Rome 'La Sapienza'; \\ ${ }^{5}$ Division of Surgery, Cutroni-Zodda Hospital, Barcellona Pozzo di Gotto (Messina), Italy
}

Received June 19, 2007; Accepted August 23, 2007

\begin{abstract}
Many studies have demonstrated that both normal and malignant prostate cells respond to a variety of growth factors, while several significant differences were found between normal and tumoural cells. The aim of this study was to focus on the localization and distribution of the immuno-reactivity for neurotrophins (NTs) and neurotrophin receptors (NTRs) in normal, hyperplastic and prostate cancer cells, obtained from 40 subjects. We studied samples obtained from 16 prostate cancer (PC, retropubic radical prostatectomy), 20 benign prostatic hyperplasia (BPH, supra-pubic prostatectomy) and normal peripheral prostate tissue from four fresh male cadavers. Samples were examined via immunohistochemical techniques in order to detect the expression of nerve growth factor (NGF), brain derived neurotrophic factor (BDNF), neurotrophin 3 (NT3) and their own receptors TrkA, p75, TrkB and TrkC. We observed a high expression of BDNF and TrkB in $\mathrm{PC}$ and $\mathrm{BPH}$, though no immuno-reactivity was found for $\mathrm{p} 75$. Low expression was reported by other NTs and NTRs in the normal peripheral prostate zone, BPH and PC. These data suggest a possible predictive role for NTs and NTRs, especially for BDNF and TrkB, in the diagnosis and/or management of prostate cancer. The absence of p75 expression confirms its supposed role in apoptotic phenomenon.
\end{abstract}

\section{Introduction}

The physiological role of neurotrophins (NTs) in promoting differentiation and survival of developing neurons in the central and peripheral nervous system has been widely defined

Correspondence to: Professor Elena Bronzetti, 'La Sapienza' University of Rome, Department of Cardiovascular, Respiratory and Morphological Sciences, Via A. Borelli 50, 00161 Rome, Italy E-mail: elena.bronzetti@uniroma1.it

Key words: prostate, cancer, immunohistochemistry, neurotrophins, brain derived neurotrophic factor
(1); moreover, NTs stimulate differentiation and proliferation of several cell types of all three germ layers $(2,3)$. NTs and nerve growth factor (NGF) play an important role in the modulation of several human malignancies and are involved in the stimulation of clonal growth of tumour cells in vitro, via high affinity NT receptors (4). Certain tumours have been shown to be non-responsive to NGF in vitro, whereas NGF has been shown to be mitogenic for cultured cells from medullary thyroid carcinoma, breast and prostate cancer (4).

Paracrine and autocrine mechanisms play an important role in the control of normal and pathologic growth of the prostate $(5,6)$, with primary involvement of growth factors and their receptors (7). Insulin-like growth factor-I (IGF-I), epidermal growth factor and transforming growth factor- $\alpha$ exert their biological effects on prostate epithelium, while peptides of the fibroblast growth factor (FGF) family are considered essential factors for prostate proliferation: changes in the expression of FGF and/or FGF receptors positively correlate with the malignant progression.

A large series of studies have demonstrated that both normal and malignant prostate cells respond to a variety of these growth factors, while several significant differences were reported between normal and tumoural cells. NGF and its receptors TrkA and p75 were identified in the reproductive organs of normal adult male rats (8) including the prostate.

NGF has also been identified in the human prostate, at the stromal compartment level, while normal prostatic epithelial cells do not secrete detectable levels of NGF (and/or other NTs). Normal prostate epithelium does not depend on the axis NGF - receptors (TrkA, p75) for its survival. The modulatory action of a GF-like protein released by prostatic stromal cells indicates a paracrine function for NGF in the control of prostatic growth. The NGF action is exerted by means of stimulation of a high affinity receptor, member of the tyrosine kinase receptor family, called $\mathrm{p} 140^{\text {trka }}$ and a low-affinity highcapacity trans-membrane receptor, the p $75^{\mathrm{LNGFR}}$, whose signal has not been completely elucidated (4). NGF is capable of stimulating a proliferative response via the high affinity Trk receptor and alternatively, can mediate programmed cell death via the low-affinity $\mathrm{p} 75^{\mathrm{NTR}}$ receptor. On the other hand, the correspondent Trk receptor is present in normal, malignant prostate epithelia and in tumour cell lines, whereas the $\mathrm{p} 75^{\mathrm{NTR}}$ receptor is progressively lost from the 
malignant prostate and is not expressed in prostate tumour cell lines derived from metastases.

Although the role of NGF and its receptors has been fairly well-clarified $(4,9)$, it still remains to be established which prostatic cell types produce NGF. Furthermore, it is known that normal prostate synthesizes BDNF and NT3 (4), but it has not been defined which prostate cell line is involved in this mechanism and it is still debated which specific changes of NTs take place during prostate cancer progression.

Since only the NGF role has been widely analysed in the prostate, the present study was designed to investigate the expression and distribution of immunoreactivity for BDNF and NT3, in order to quantify their distribution in comparison with NGF. The results of our study are discussed in light of the available literature.

\section{Materials and methods}

Clinical material. We analysed 16 samples of prostate cancer (PC), obtained from retropubic radical prostatectomy and 20 samples from benign prostatic hyperplasia (BPH), obtained from supra-pubic trans-vesical prostatectomy (entire adenomas). We obtained four whole prostates from four fresh male cadavers who had not died from tumoural prostatic disease, in order to obtain a healthy peripheral prostatic tissue to compare with other samples. Patients affected by prostate cancer were aged from 57 to 69 years (mean age $63 \mathrm{yrs}$ ); serum PSA levels ranged from $4.7 \mathrm{ng} / \mathrm{ml}$ to $13.34 \mathrm{ng} / \mathrm{ml}$ (mean value $9.02 \mathrm{ng} / \mathrm{ml}$ ). Only three subjects (aged 58, 59 and 63) were positive at the digitorectal examination (DRE); in these patients trans-rectal ultrasounds (TRUS) revealed hypo-echoic peripheral areas. Cancer diagnosis was obtained via transperineal ultrasound-guided prostate biopsy (TPUS), performed in out-patient regime. A minimum of 12 to a maximum of 18 bioptic cores were obtained from all subjects. Gleason score ranged from a minimum of 5 (3 and 2 in one subject aged $66, \mathrm{PSA}=5.1 \mathrm{ng} / \mathrm{ml}$ ) to a maximum of 8 (two patients 5 and 3 , aged 57 and 69, serum PSA levels respectively $9.05 \mathrm{ng} / \mathrm{ml}$ and $6.9 \mathrm{ng} / \mathrm{ml}$, and two patients 4 and 4, aged 61 and 68, serum PSA respectively $13.34 \mathrm{ng} / \mathrm{ml}$ and $12.09 \mathrm{ng} / \mathrm{ml})$. The $16 \mathrm{PC}$ subjects each provided a written informed consent then underwent retro-pubic radical prostatectomy; a bilateral iliac-obturator lymphectomy was performed on 13 subjects. The diagnosis was prostatic adenocarcinoma in all patients, with a Gleason score ranging from 6 to 8; the score of 6 was obtained from the patient with the pre-operative Gleason score $=5$. The other scores confirmed the pre-operative bioptic ones. The 20 entire prostate adenomas were obtained from trans-vesical suprapubic prostatectomy performed on 20 male patients aged from 62 to 78 years (mean age 70). Patients were affected by BPH with severe lower urinary tract symptoms (LUTS) diagnosed via urodynamics, TRUS with post-voiding residue and International Prostate Symptom Score (IPSS): these 20 subjects were selected for supra-pubic prostatectomy, with a prostate volume $>80 \mathrm{ml}$ (the prostate volume was calculated with the TRUS prolate ellipse volume measurement). The PSA serum level in all subjects ranged from 2.3 to $6.9 \mathrm{ng} / \mathrm{ml}$ (three patients with PSA of $>4 \mathrm{ng} / \mathrm{ml}$ underwent a pre-operative prostate biopsy in order to exclude prostate cancer diagnosis): BPH patients signed a written informed consent before surgery. Four healthy prostate samples were obtained from fresh male cadavers aged between 57 and 69 (mean age 63): the cause of death was acute cardiovascular failure. After a written consent obtained from the relatives, we proceeded to remove the whole prostate from the cadavers; the prostates were fixed in formaldehyde and histologically examined to exclude prostate cancer. We analysed the peripheral healthy zone of the whole glands, to utilize them as control cases.

The presence of neurotrophins and their receptors in all prostate samples (PC, BPH and control cases) was detected by using immunohistochemical techniques.

Immunohistochemical analysis. The following molecules were investigated: nerve growth factor (NGF), brain derived neurotrophic factor (BDNF), neurotrophin 3 (NT3) and certain neurotrophin receptors such as tyrosine kinase $\mathrm{A}$ (TrkA), tyrosine kinase B (TrkB), tyrosine kinase C (TrkC) and protein 75 (p75).

Experiments were performed in compliance with the Italian laws and guidelines concerning the informed consent of the patients or (for autoptic cases) their relatives. Surgical samples of prostate were removed, fixed in formalin and embedded in paraffin. Serial $5 \mu \mathrm{m}$ thick sections were obtained using a rotatory microtome, mounted on gelatin-coated slides and processed for immunohistochemistry as described (10). The following molecules were investigated: nerve growth factor (NGF), brain derived neurotrophic factor (BDNF), neurotrophin 3 (NT3), tyrosine kinase A (TrkA), tyrosine kinase B (TrkB), tyrosine kinase $\mathrm{C}($ TrkC) and protein 75 (p75).

To study the immunolocalization of neurotrophins and their receptors, the following antibodies were used: i) rabbit anti-nerve growth factor (anti-NGF) polyclonal antibody (Santa Cruz, CA, USA) which displayed $<1 \%$ cross-reactivity against recombinant human NT-3 and BDNF; ii) rabbit antityrosine kinase A (anti-TrkA) polyclonal antibody (Santa Cruz), which recognized an epitope corresponding to aminoacids 763 to 777 , mapping adjacent to the carboxyterminus of human TrkA p140; iii) goat polyclonal antibody to human p75 NT receptor (Santa Cruz), which recognized the amino acid sequence mapping the carboxy-terminus of the $\mathrm{p} 75^{\mathrm{NT}}$ receptor precursor of human origin; iv) rabbit anti-brain derived neurotrophic factor (anti-BDNF) polyclonal antibody (Santa Cruz), which recognized the amino-terminal of mouse BDNF; v) rabbit anti-tyrosine kinase B (anti-TrkB) polyclonal antibody (Santa Cruz), which recognized an epitope corresponding to amino acids 794 to 808 of mouse TrkB p145; vi) rabbit anti-neurotrophin 3 (anti-NT-3) polyclonal antibody (Santa Cruz), which was raised against the aminoterminal of mouse NT-3; vii) rabbit polyclonal anti-tyrosine kinase C (anti-TrkC) antibody (Santa Cruz), which recognized an epitope corresponding to amino acids 798 to 812 of porcine TrkC $\mathrm{p} 140$.

The specificity of antibodies for corresponding peptides was assessed by Western blotting (data not shown) using homogenates of rat brain as NT and NT receptor source with the exception of human B-NGF used as a standard in this control experiment. From each paraffin block, consecutive sections were exposed to anti-TrkA, anti-TrkB, anti-TrkC, 
Table I. Neurotrophins and neurotrophin receptors in the control, BPH and PC prostates.

\begin{tabular}{|c|c|c|c|}
\hline & Control & $\mathrm{BPH}$ & $\mathrm{PC}$ \\
\hline NGF & $\begin{array}{l}\text { Ductal epith. } \\
\text { Macrophages + } \\
\text { Fibroblasts + } \\
\text { Lymphocytes } \\
\text { Blood vessels + }\end{array}$ & $\begin{array}{l}\text { Ductal epith. + } \\
\text { Macrophages + } \\
\text { Fibroblasts + } \\
\text { Lymphocytes + }\end{array}$ & $\begin{array}{l}\text { Ductal epith. ++ } \\
\text { Macrophages + } \\
\text { Fibroblasts + } \\
\text { Lymphocytes + }\end{array}$ \\
\hline TrkA & $\begin{array}{l}\text { Ductal epith. + } \\
\text { Macrophages + } \\
\text { Fibroblasts + } \\
\text { Lymphocytes }\end{array}$ & $\begin{array}{l}\text { Ductal epith. + } \\
\text { Macrophages ++ } \\
\text { Fibroblasts + } \\
\text { Lymphocytes + }\end{array}$ & $\begin{array}{l}\text { Ductal epith. ++ } \\
\text { Macrophages + } \\
\text { Fibroblasts + } \\
\text { Lymphocytes + }\end{array}$ \\
\hline P75 & Negative & Negative & Negative \\
\hline BDNF & $\begin{array}{l}\text { Ductal epith. } \\
\text { Macrophages + } \\
\text { Fibroblasts + } \\
\text { Lymphocytes } \\
\text { Blood vessels + }\end{array}$ & $\begin{array}{l}\text { Ductal epith. ++ } \\
\text { Macrophages ++ } \\
\text { Fibroblasts }++ \\
\text { Lymphocytes }++ \\
\text { Corpora amilacea ++ }\end{array}$ & $\begin{array}{l}\text { Ductal epith. +++ } \\
\text { Macrophages }+++ \\
\text { Fibroblasts }+++ \\
\text { Lymphocytes+++ } \\
\text { Corpora amilacea +++ }\end{array}$ \\
\hline TrkB & $\begin{array}{l}\text { Ductal epith. + } \\
\text { Macrophages + } \\
\text { Fibroblasts }+ \\
\text { Lymphocytes } \\
\text { Blood vessels }\end{array}$ & $\begin{array}{l}\text { Ductal epith. ++ } \\
\text { Macrophages ++ } \\
\text { Fibroblasts ++ } \\
\text { Lymphocytes ++ }\end{array}$ & $\begin{array}{l}\text { Ductal epith. +++ } \\
\text { Macrophages +++ } \\
\text { Fibroblasts +++ } \\
\text { Lymphocytes +++ } \\
\text { Blood vessels ++ }\end{array}$ \\
\hline NT3 & $\begin{array}{l}\text { Ductal epith. + } \\
\text { Macrophages + } \\
\text { Fibroblasts }+ \\
\text { Lymphocytes } \\
\text { Blood vessels }\end{array}$ & $\begin{array}{l}\text { Ductal epith. ++ } \\
\text { Macrophages + } \\
\text { Fibroblasts }+ \\
\text { Lymphocytes + } \\
\text { Blood vessels + }\end{array}$ & $\begin{array}{l}\text { Ductal epith. ++ } \\
\text { Macrophages ++ } \\
\text { Fibroblasts ++ } \\
\text { Lymphocytes ++ } \\
\text { Blood vessels ++ }\end{array}$ \\
\hline TrkC & $\begin{array}{l}\text { Ductal epith. + } \\
\text { Macrophages+ } \\
\text { Fibroblasts + } \\
\text { Lymphocytes } \\
\text { Blood vessels }\end{array}$ & $\begin{array}{l}\text { Ductal epith. } \pm \\
\text { Macrophages } \pm \\
\text { Fibroblasts } \pm \\
\text { Lymphocytes } \pm\end{array}$ & $\begin{array}{l}\text { Ductal epith. }+ \\
\text { Macrophages } \pm \\
\text { Fibroblasts } \pm \\
\text { Lymphocytes } \pm\end{array}$ \\
\hline
\end{tabular}

anti-NT3 (diluted 1:100), anti-p75 (diluted 1:10) and to antiNGF, anti-BDNF and anti-NT-3 antibodies (diluted 1:1000) and to the antibodies pre-adsorbed with human NGF $(10 \mu \mathrm{g} /$ $\mathrm{ml})$, human BDNF blocking peptide $(10 \mu \mathrm{g} / \mathrm{ml})$, human NT-3 $(10 \mu \mathrm{g} / \mathrm{ml})$.

Optimal antisera dilutions and incubation times were assessed in a series of preliminary experiments. After incubation, slides were rinsed twice in phosphate buffer and exposed for $30 \mathrm{~min}$ at $25^{\circ} \mathrm{C}$ to secondary antibodies raised against rabbit (anti-rabbit for Trk and NT immunohistochemistry) (Boehringer Mannheim GmbH, Mannheim, Germany), against mouse (anti-mouse for p75NT receptor immunohistochemistry) (Sigma Chemicals Co, St. Louis, MO, USA) secondary antibodies conjugated with horseradish peroxidase at a dilution of 1:100. The product of immune reaction was revealed by using $0.05 \%$ 3,3-diaminobenzidine in $0.1 \% \mathrm{H}_{2} \mathrm{O}_{2}$ as a chromogen. Sections were then washed, dehydrated in ethanol, mounted in a synthetic mounting medium and observed by using a light microscope. Endogenous peroxidase activity was blocked by $\mathrm{H}_{2} \mathrm{O}_{2}$, while the non-specific binding of immunoglobulin to glass and tissue was prevented by $3 \%$ fetal calf serum added to the incubation medium. In a series of preliminary experiments, immunohistochemistry was performed using both paraffinembedded and frozen sections (data not shown). No differences in the intensity or distribution of immunostaining were noticeable using the 2 types of sections, although micro-anatomical details were better preserved in paraffinembedded material. As reported by Nohr et al (11), we employed paraffin-embedded material in standard immunohistochemistry experiments. The intensity of the immune reaction was assessed microdensitometrically by a program of an IAS 2000 image analyzer (Delta Sistemi, Rome, Italy) connected via a TV camera to the microscope. Sections were examined at a final x200 magnification. The system was calibrated taking as zero the background obtained in sections 


\section{NGF-TrK A}

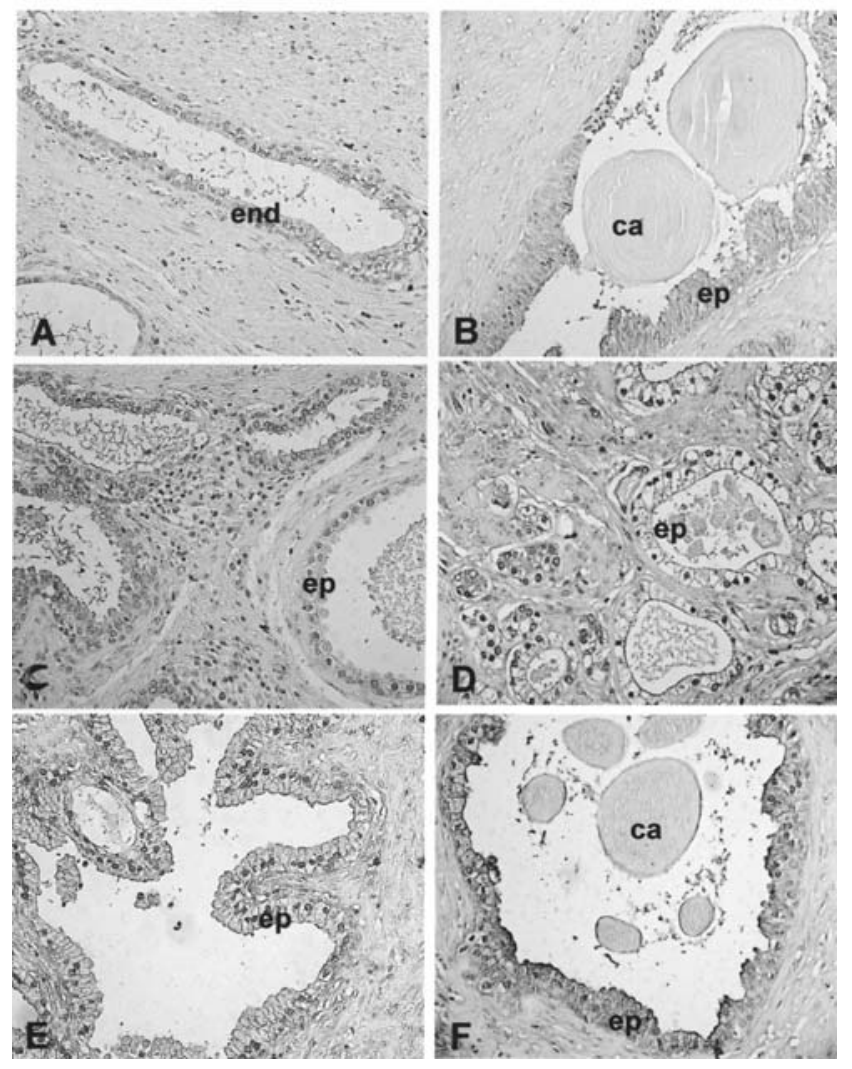

Figure 1. (A, B) Normal prostate (control); (C, D) prostate hypertrophy; (E, F) prostatic cancer; ep, epithelium; end, endothelium; ca, amylacea corpora.

\section{BDNF-TrK B}
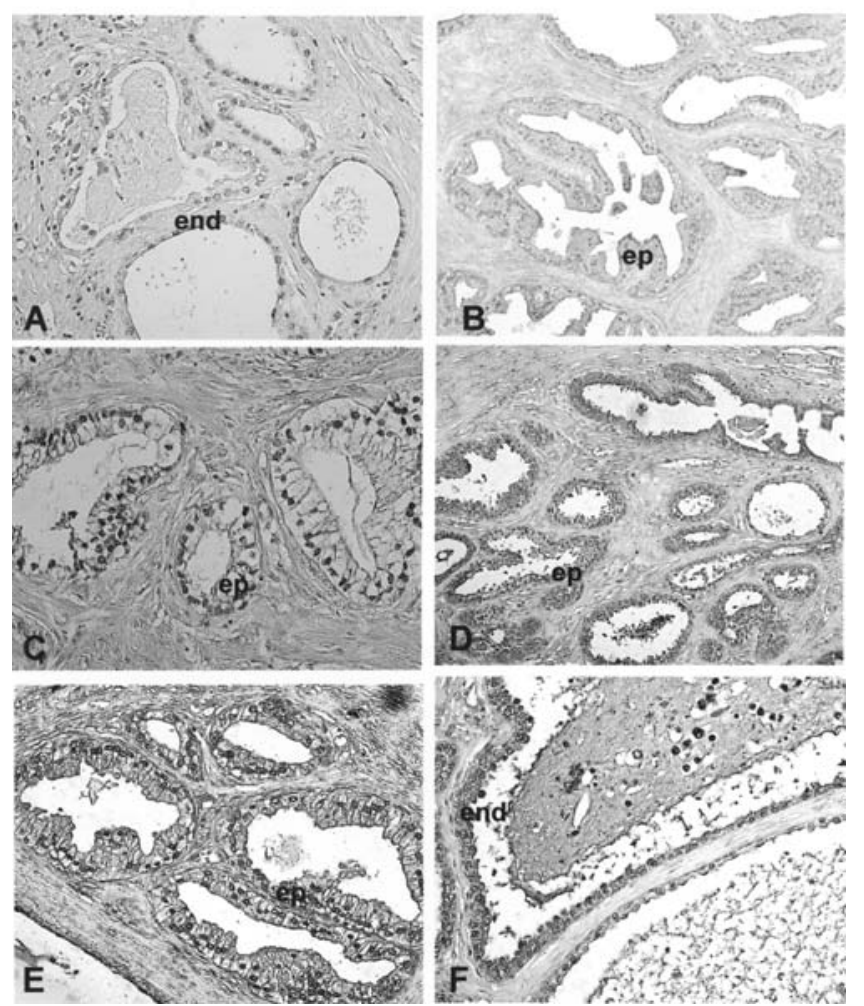

Figure 2. (A, B) Normal prostate (control); (C, D) prostate hypertrophy; (E, F) prostatic cancer; ep, epithelium; end, endothelium; ca, amylacea corpora.

\section{NT3-TrK C}

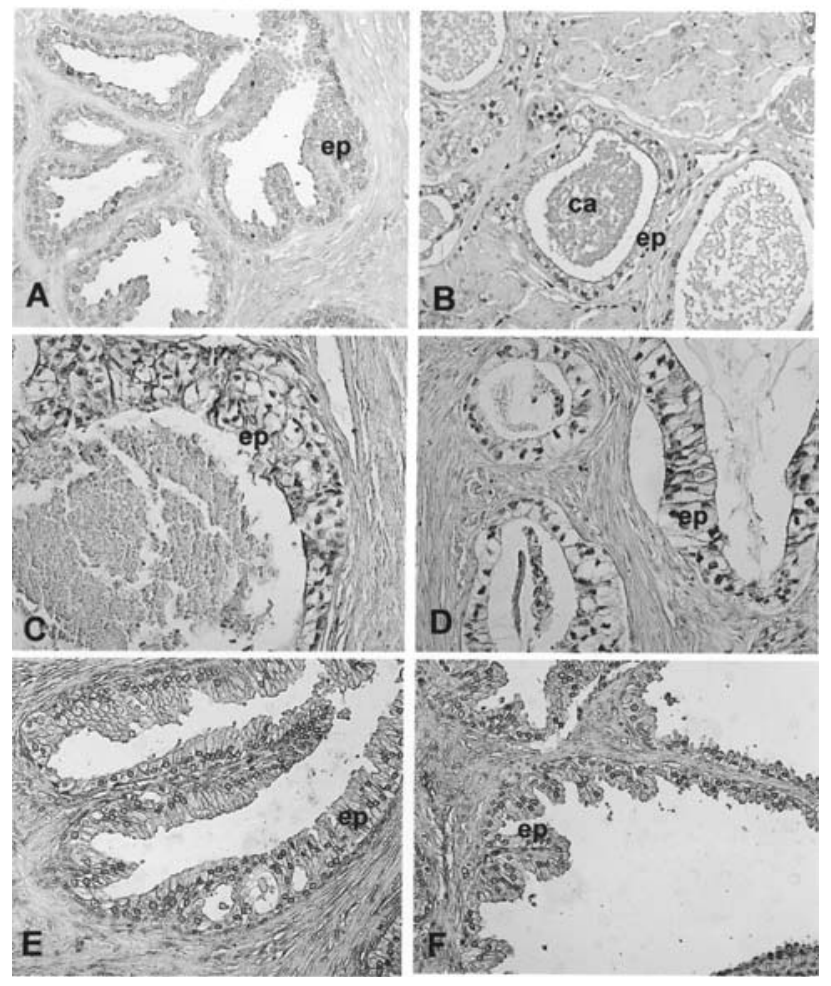

Figure 3. (A, B) Normal prostate (control); (C, D) prostate hypertrophy; (E, F) prostatic cancer; ep, epithelium; end, endothelium; ca, amylacea corpora.

exposed to pre-immune serum. Ten $100 \mathrm{~mm}^{2}$ areas were delineated in each section by a measuring diaphragm. Data of quantitative analysis of the intensity of the immune staining for neurotransmitters, NTs and NT receptors in the examined tissues were analyzed statistically by analysis of variance (ANOVA) followed by Duncan's multiple range test as a post hoc test.

\section{Results}

Neurotrophins and their receptors are expressed in prostate blood vessels, glandular ductal epithelium and also in the stromal cells (macrophages, fibroblasts and lymphocytes) (Table I). NGF and TrkA show a weak expression in the control, BPH and PC samples (Fig. 1). The low affinity NGF receptor p75 had no expression in our cases (data not shown). BDNF and TrkB immunoreactivity was detected in all samples, showing higher expression in $\mathrm{BPH}$ and $\mathrm{PC}$ in comparison with the control cases (Fig. 2). NT3 was marked in $\mathrm{BPH}$ and more in PC samples, while its receptors TrkC was weakly expressed in all cases (Fig. 3).

On the basis of our data, BDNF proved to be the most expressed neurotrophin among the NT clusters studied: its receptor TrkB confirmed these data, showing an elevated immunoreactivity; furthermore, their immunostaining was evident, mainly in PC samples.

\section{Discussion}

There is a variety of growth factors and cytokines, which can potentially provide the activation of tumour survival pathways, 
including fibroblast growth factors, epidermal growth factor, insulin-like growth factors (IGF) I/II, platelet-derived growth factor (PDGF), neurotrophins such as nerve growth factor (NGF) and interleukins (IL) such as IL-6 or -10. Each of these factors is known to initiate its effect by binding to its cell surface cognate receptors and inducing and/or activating receptor polymerization, which activates the intracellular tyrosine kinase domain of each receptor monomer, allowing it to trans-phosphorylate specific sites in the intracellular domain of other receptor monomers in the complex. The tyrosine trans-autophosphorylation is the most relevant among polymerized receptor functions to recruit intracellular signalling proteins to bind via their src homology (i.e., $\mathrm{SH}_{2}$ ) domains to specific phosphorylated tyrosines in the ligandoccupied polymeric receptor complex. This autophosphorylation initiates a variety of kinase-dependent signalling cascades that regulate cell survival. The neurotrophins include NGF, BDNF, NT-3 and neurotrophin 4/5 (NT 4/5): each of these factors binds with high affinity to a specific subtype of the $140-\mathrm{kDa}$ neurotrophin receptor family, known as Trk receptors. For NGF, the specific receptor is TrkA, for BDNF and neurotrophin-4/5 it is TrkB and for NT-3 it is TrkC.

Pflug et al (12) demonstrated that normal human prostatic glandular cells express high-affinity $\left(\mathrm{K}_{\mathrm{d}}=\sim 1 \mathrm{x} 10-11 \mathrm{M}\right) \mathrm{NGF}$ receptors (Scatchard binding analysis). On the basis of the immunocytochemical results Shibayama and Koizumi $(3,13)$ confirmed that normal human prostate epithelial cells specifically express TrkA, but not TrkB or TrkC receptors. Weeraratna et al (14) further demonstrated that TrkA is homogeneously expressed in $60 \%$ of primary prostate cancers and $80 \%$ of metastatic sites in untreated patients. Their studies demonstrated that $60-70 \%$ of primary and metastatic sites express the TrkB and $\mathrm{C}$ receptor. Combining these results, $>90 \%$ of prostate cancer cases express at least one of the Trk receptors.

The neurotrophins can bind with lower affinity to $75-\mathrm{kDa}$ plasma membrane proteins known as p75 NTR receptor whose function is unclear, although it belongs to the TNF $\alpha$ $55-\mathrm{kDa}$ family of plasma membrane receptor proteins. This receptor is present in normal human prostate, where it is localized to the TrkA expressing epithelium. Perez et al (15) demonstrated that the loss of $\mathrm{p} 75^{\mathrm{NTR}}$ expression occurs during the progression of prostate cancer, resulting in the elimination of this negative growth regulatory pathway during tumorigenesis (14). It was therefore proposed that the expression of p $75^{\mathrm{NTR}}$ in developing cells may force the cells into a choice: in the absence of a trophic support, apoptosis is induced, whereas in the presence of trophic support, survival is enhanced. This profile supports $\mathrm{p} 75^{\mathrm{NTR}}$ as a candidate for mediation of the phenomenon of neurotrophin dependence. Other authors (15) demonstrated that $\mathrm{p} 75^{\mathrm{NTR}}$ retards cell cycle progression by the induced accumulation of cells in G0/G1 and a reduction in the S phase of the cell cycle. Moreover, according to the same authors, the rescue of tumour cells from cell cycle progression by a death domain deleted (Delta DD) dominant-negative antagonist of p75 ${ }^{\mathrm{NTR}}$ showed that the death domain transduced anti-proliferative activity in a ligand-independent manner. Conversely, the addition of NGF ligand rescued retardation of cell cycle progression with proportional changes in components of the cyclin/cdk holoenzyme complex. In the absence of ligand p75 $5^{\mathrm{NTR}}$ dependent cells cycle arrest facilitated an increase in apoptotic nuclear fragmentation of the prostate cancer cells. However, evaluation of cells co-expressing $\mathrm{p} 75^{\mathrm{NTR}}$ and TrkA, B or C is complicated by their putative effects on one another.

Our results report that the malignancy of PC seems to be accompanied by increased TrkB signalling, with a reduced immunoreactivity for TrkA and a complete absence of p75 expression. According to recent data reported by Festuccia et al (16) TrkA and mainly, TrkB expression, seems to be related to the invasive capacity/malignancy of PC cells; p75 can be considered as a tumour suppressor factor for its demonstrated retarding role in cell cycle progression. The relevant distribution of the immunoreactivity for NTs, with special reference to BDNF and its receptor, may be useful for planning further research regarding BDNF as a kind of 'predictive marker' of proliferation in the sense of truly neoplastic progression in biopsies or in surgical specimens. According to recent studies (17) BDNF and its own receptor TrkB are involved in a variety of human cancers, in which TrkB plays a role in the initiation of carcinomas. Overexpression of these molecules is often correlated to angiogenesis, malignancy and aggressivity, suggesting that TrkB may be used as a valuable target for cancer therapy. This hypothesis, supported by the over-expression of BDNF in specimens obtained from patients with prostate cancer, may be confirmed by analyzing the potential trophic, stimulatory and regulatory role of the progression of prostatic adenocarcinomatous cells in future studies.

\section{References}

1. Barbacid M: The Trk family of neurotrophin receptors. J Neurobiol 25: 1386-1403, 1994.

2. Thomson TM, Rettig WJ, Chesa PG, Green SH, Mena AC and Old LJ: Expression of human nerve growth factor receptor on cells derived from all three germ layers. Exp Cell Res 174: 533-539, 1988.

3. Shibayama E and Koizumi H: Cellular localization of the Trk neurotrophin receptor family in human non-neuronal tissues. Am J Pathol 148: 1807-1818, 1996

4. Sortino MA, Condorelli F, Vancheri C, Chiarenza A, Bernardini R, Consoli U and Canonico PL: Mitogenic effect of nerve growth factor (NGF) in $\mathrm{LNCaP}$ prostate adenocarcinoma cells: role of the high- and low-affinity NGF receptors. Mol Endocrinol 14: 124-136, 2000

5. Cunha GR, Ricke W, Thomson A, et al: Hormonal, cellular, and molecular regulation of normal and neoplastic prostatic development. J Steroid Biochem Mol Biol 92: 221-236, 2004.

6. Chung LW, Huang WC, Sung SY, et al: Stromal-epithelial interaction in prostate cancer progression. Clin Genitourin Cancer 5: 162-170, 2006

7. Steiner MS: Role of peptide growth factors in the prostate: a review. Urology 42: 99-110, 1993.

8. Li C, Watanabe G, Weng Q, et al: Expression of nerve growth factor (NGF), and its receptors TrkA and p75 in the reproductive organs of the adult male rats. Zoolog Sci 22: 933$937,2005$.

9. Paul JW, Quach TT, Duchemin AM, Schrier BK and DaVanzo JP: 1,1,3 tricyano-2-amino-1-propene (Triap): a small molecule which mimics or potentiates nerve growth factor. Brain Res Dev Brain Res 55: 21-27, 1990.

10. Bronzetti E, Ciriaco E, Germanà G and Vega JA: Immunohistochemical localization of neurotrophin receptor proteins in human skin. Ital J Anat Embryol 100: 565-571, 1995.

11. Nohr D, Buob A, Gartner K and Weihe E: Changes in pulmonary calcitonin gene-related peptide and protein gene product 9.5 innervation in rats infected with Mycoplasma pulmonis. Cell Tissue Res 283: 215-219, 1996. 
12. Pflug BR, Pecher SM, Brink AW, Nelson JB and Foster BA: Increased fatty acid synthase expression and activity during progression of prostate cancer in the TRAMP model. Prostate 57: 245-254, 2003.

13. Koizumi F, Noguchi Y, Saika T, et al: XAGE-1 mRNA expression in prostate cancer and antibody response in patients. Microbiol Immunol 49: 471-476, 2005.

14. Weeraratna AT, Dalrymple SL, Lamb JC, Denmeade SR, Miknyoczki S, Dionne CA and Isaacs JT: Pan-trk inhibition decreases metastasis and enhances host survival in experimental models as a result of its selective induction of apoptosis of prostate cancer cells. Clin Cancer Res 7: 2237-2245, 2001.
15. Perez M, Regan T, Pflug B, Lynch J and Djakiew D: Loss of low-affinity nerve growth factor receptor during malignant transformation of the human prostate. Prostate 30: 274-279, 1997.

16. Festuccia C, Muzi P, Gravina GL, et al: Tyrosine kinase inhibitor CEP-701 blocks the NTRK1/NGF receptor and limits the invasive capability of prostate cancer cells in vitro. Int J Oncol 30: 193-200, 2007.

17. Han L, Zhan Z, Qin W and Sun W: Neurotrophic receptor TrkB: is it a predictor of poor prognosis for carcinoma patients? Med Hypotheses 68: 407-409, 2007. 